\title{
Reading Effectively Across the Disciplines (READ): A Strategy to Improve Student Success
}

\author{
Juanita C. But, PhD \\ Associate Professor, Department of English \\ New York City College of Technology of the City University of New York \\ Pamela Brown, PhD \\ Associate Provost \\ New York City College of Technology of the City University of New York \\ Davida S. Smyth, PhD \\ Associate Professor and Chair, Department of Natural Sciences \\ Mercy College
}

This paper describes the structure and activities of READ (Reading Effectively Across the Disciplines), a pilot initiative to improve students' critical reading skills, disciplinary literacy and academic success. READ employs a multimodal design that consists of faculty training

in disciplinary literacy instruction and curricular enhancement, development and implementation of active reading assignments and assessments, peer-led team learning, and the dissemination of discipline-specific teaching and learning resources on an Open Lab site to provide an interactive teaching and learning environment for students and faculty. Empirical evidence of the initial effectiveness of the pilot in three gateway courses in Biology, Electromechanical Engineering Technology, and Marketing showed improvement in student pass rates after implementation of reading strategies and instructional approaches that guide students through the reading process.

College reading requires skills and strategies that differ from those required for high school reading in many ways. Even though college and high school courses may carry similar titles, college courses are more challenging due to a larger amount of material covered, demanding learning goals, and more diverse and complex reading requirements (Conley 2007, 2008; Conley, Aspengren, Stout, \& Veach, 2006). Given the greater breadth and depth of content knowledge taught in college courses, students need a series of advanced thinking and learning skills, both general and disciplinespecific, to succeed.

Among these skills are effective textual engagement and deep understanding of texts, which require inferential and elaborative processing (Graesser, Millis, \& Zwaan, 1997; Kintsch \& Rawson, 2005; Pressley \& Afflebach, 1995). Evidence suggests that students generally do not develop these skills extensively in high school (Conley et al., 2006). Studies in cognitive developmental processes indicate that students are still acquiring the ability to use and understand adverbial conjuncts and idiomatic interpretation late in high school (Chapman, 1983; Nippold \& Martin, 1989). In addition, inferential reasoning, abstract thinking, and recognition and use of structure/features, are developed only with maturity and experience (Chambliss, 1995; Kletzien, 1992). As Conley (2007) points out, in college courses,

students are expected to make inferences, interpret results, analyze conflicting explanations of phenomena, support arguments with evidence, solve 
complex problems that have no obvious answer, reach conclusions, offer explanations, conduct research, engage ideas, and generally think deeply about what they are being taught. (p. 6)

These are the thinking and reasoning skills that students may not readily possess and apply while reading as they enter college. Another challenge that they face is their lack of background knowledge of both content and structure (Moore \& Scevak, 1997), especially for certain discipline-specific and discipline-related texts.

From the perspective of disciplinary literacy education, the question is not whether reading should be taught, but what, how, and where it should be taught in college, and who should be involved in the process. College reading is disciplinespecific (Fang \& Schleppegrell, 2010; Shanahan \& Shanahan, 2008) and literacy varies in different domains (Alexander, Schallert, \& Hare, 1991). Disciplinary literacy is characterized by "the ways of thinking, knowing, and doing that are consistent with each discipline," rather than by "a set of strategies instructors use to help students organize text or make connections among words" (Zygouris-Coe, 2012, para. 2). In this sense, reading, as disciplinary literacy, should be taught not just in English courses, contrary to the perception of many, but also in the content areas. Content area faculty should make reading requirements clear, understand their students' ability, and introduce strategies to facilitate discipline-specific thinking and critical reading of text material. It is important to know that they are not expected to teach students to learn to read, but to read to learn in the disciplines (Richardson, Morgan \& Fleener, 2012). Lastly, college reading requires faculty to engage students by using relevant assessments and approaches to enable them to develop their own strategies while reading in the disciplines and become independent readers.

\section{Development of the READ program}

Two institutional challenges framed the development of the READ program: (1) a college-wide general education reading assessment, which suggested that over $70 \%$ of students were found to struggle with college-level reading, much greater than the national average of 52\% (ACT, 2012), and: (2) a university funding opportunity to develop, implement and evaluate student success initiatives to increase pass rates in gateway courses where over 100 students failed in Fall 2011. Our proposal included funding to develop and implement professional development initiatives for faculty to cultivate the skills to enhance students' reading skills in various disciplines through collaborative effort between reading and content area faculty, disseminate developed curricular materials, provide student stipends for peer led team learning, and assess activities. In Fall 2012, we were awarded funding. From Spring 2013 to Spring 2014, we focused on enhancing student performance in three gateway courses - Biology I (BIO 1101), Essentials of Marketing (MKT 1100), and Electromechanical Manufacturing Laboratory (EMT 1130), all with more than 100 students not successfully completing the course (withdrew or failed) in Fall 2011.

This paper describes the structure and activities of READ. We hypothesized that our students' low level of college readiness in reading was due to their lack of vocabulary skills and the active reading strategies needed to become effective readers and learners in the disciplines. Instead of engaging in reading-to-learn, struggling 
readers often rely on their listening skills in class (Schemo, 2006). Even for students who read their text, many only accumulate facts and memorize correct answers while not able to engage with the text and practice the metacognitive thinking needed. We further hypothesized that effective instruction of active reading strategies and vocabulary skills in the content areas would improve students' general and disciplinespecific reading and thinking skills and enable them to become independent readers, and thereby achieve greater success in their courses. While focusing mainly on delivering content knowledge, instructors across the disciplines often overlook the importance of reading proficiency and do not feel ready to address the challenges students face in reading text material (Hall, 2005; Stewart and O'Brien 1989). It is also common that faculty across the disciplines lack instructional and assessment strategies that scaffold reading assignments to guide students through the reading-to-learn process.

As our college is an open access, public, minority serving institution, we further hypothesized that by incorporating evidence-based practices, such as peer led team learning (PLTL), we would further advance our goal to improve pass rates. With PLTL, more advanced, successful undergraduate students are trained as peer leaders to facilitate small group learning. These peer-led groups meet weekly, separate from the lecture and the instructor. Peer leaders do not provide answers, but instead ask leading questions to promote students working together to solve problems that are structured to help them develop conceptual understanding and problem-solving skills. PLTL has been demonstrated to lead to increased student success, particularly among minority students (Snyder, Sloane, Dunk, \& Wiles, 2016).

To test our hypothesis to improve our students' critical reading skills, disciplinary literacy and academic success, we embed literacy into content instruction to engage students in the reading-to-learn process within the discipline. The effectiveness of this approach relies on the practice that literacy specialists assist content area instructors to identify literary practices unique to their disciplines. As Moje (2008) suggests, "it may be most productive to build disciplinary literacy instructional programs, rather than to merely encourage content teachers to employ literacy teaching practices and strategies" (p. 96). As supported by research over the past decades, disciplinary literacy instruction is crucial to improving literacy skills and knowledge acquisition (Alexander \& Jetton, 2000; Alvermann \& Moore, 1991; Meltzer, 2002).

\section{Method}

READ is a multi-component program in which reading and content area faculty work together to design discipline-specific reading strategies to improve student learning in selected courses. The four program components are faculty development, Peer-Led Team Learning (PLTL), reading assessments, and a READ Open Lab website. The activities involved in the implementation of READ are shown in Table 1. 
Table 1

Summary of READ activities

\begin{tabular}{|c|c|c|c|c|}
\hline Semester & $\begin{array}{l}\text { Faculty } \\
\text { Development }\end{array}$ & $\begin{array}{l}\text { Peer-led } \\
\text { Team } \\
\text { Learning } \\
\text { (PLTL) }\end{array}$ & $\begin{array}{l}\text { Open Lab } \\
\text { READ site }\end{array}$ & $\begin{array}{l}\text { READ } \\
\text { Assessment }\end{array}$ \\
\hline $\begin{array}{l}\text { Spring } \\
2013\end{array}$ & $\begin{array}{l}\text {-READ team } \\
\text { planning } \\
\text {-Introductory } \\
\text { Reading Across } \\
\text { the Curriculum } \\
\text { Workshop (led } \\
\text { by a reading } \\
\text { faculty from } \\
\text { BMCC-CUNY). } \\
\text {-College-wide } \\
\text { READ } \\
\text { workshop to } \\
\text { recruit content } \\
\text { area faculty. }\end{array}$ & $\begin{array}{l}\text {-Recruitment } \\
\text { of peer } \\
\text { leaders in } \\
\text { BIO 1100, } \\
\text { MKT 1100, } \\
\text { and EMT } \\
1130\end{array}$ & $\begin{array}{l}\text { - } \\
\text { Development } \\
\text { of discipline- } \\
\text { specific } \\
\text { reading tasks } \\
\text { and teaching } \\
\text { strategies }\end{array}$ & $\begin{array}{l}\text {-Introductory } \\
\text { Workshop: } 12 \\
\text { participants } \\
\text { from four } \\
\text { departments. } \\
\text { - College-wide } \\
\text { READ } \\
\text { workshop: } \\
\text { There were } 14 \\
\text { participants } \\
\text { from eight } \\
\text { departments. } \\
\text {-Baseline } \\
\text { reading } \\
\text { assessment in } \\
\text { selected BIO } \\
\text { 1101, MKT } 1100 \text {, } \\
\text { and EMT } 1130 \\
\text { sections }\end{array}$ \\
\hline $\begin{array}{l}\text { Summer } \\
2013\end{array}$ & $\begin{array}{l}\text {-READ faculty } \\
\text { workshop for } \\
\text { content faculty } \\
\text { teaching BIO } \\
\text { 1101, MKT } 1100 \text {, } \\
\text { and EMT } 1130\end{array}$ & $\begin{array}{l}\text {-Interviews } \\
\text { of peer } \\
\text { leaders in } \\
\text { BIO 1101, } \\
\text { MKT 1100, } \\
\text { and EMT } \\
1130\end{array}$ & $\begin{array}{l}\text {-Setting up } \\
\text { READ Open } \\
\text { Lab Biology } \\
\text { site }\end{array}$ & $\begin{array}{l}\text {-Workshop: } 16 \\
\text { participants. }\end{array}$ \\
\hline Fall 2013 & $\begin{array}{l}\text {-Reading and } \\
\text { content faculty } \\
\text { met to discuss } \\
\text { implementation, } \\
\text { challenges, and } \\
\text { modifications of } \\
\text { reading } \\
\text { strategies and } \\
\text { assessment. }\end{array}$ & $\begin{array}{l}\text {-Peer leader } \\
\text { training } \\
\text {-Embedded } \\
\text { PLTL } \\
\text { workshops in } \\
\text { one section of } \\
\text { MKT } 1100 \text { (2 } \\
\text { peer leaders); } \\
\text { and EMT } \\
1130 \text { (3 peer } \\
\text { leaders); } \\
\text { standalone }\end{array}$ & $\begin{array}{l}\text {-Continuous } \\
\text { development } \\
\text { of READ } \\
\text { Open Lab } \\
\text { Biology site }\end{array}$ & $\begin{array}{l}\text {-Pre and post- } \\
\text { reading } \\
\text { strategies } \\
\text { implementation- } \\
\text { assessments in } \\
\text { the areas of } \\
\text { comprehension, } \\
\text { interpretation, } \\
\text { context, and } \\
\text { analysis }\end{array}$ \\
\hline
\end{tabular}


Table 1

Continued

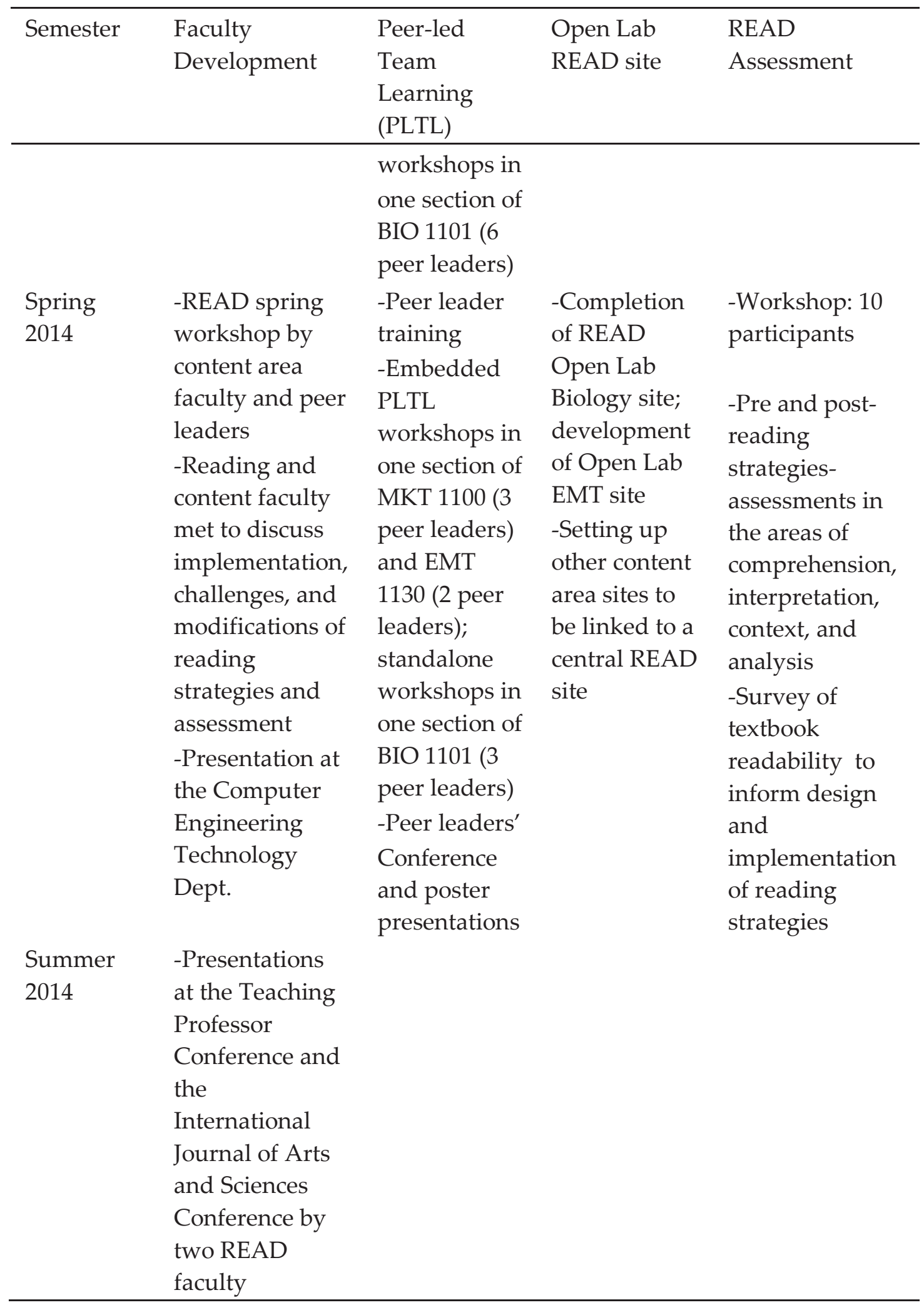


The program objectives for Fall 2013 and Spring 2014 were:

1. Equip faculty of Biology I (BIO 1101), Essentials of Marketing (MKT 1100), and Electromechanical Manufacturing Laboratory (EMT 1130) with reading strategies and related teaching-practices

2. Develop content specific assignments and teaching approaches for gateway courses to help students read and learn more effectively

3. Implement READ Peer-Led Team learning (PLTL) student workshops to enhance learning in all three disciplines

4. Evaluate the implementation of strategies-discipline specific reading assessments and teaching approaches in order to make future improvements

5. Conduct a survey to get a better understanding of faculty and students' impression of the text

\section{Participants and Courses}

The READ Team included faculty members from the departments of English (Reading specialists), Biological Sciences, Computer Engineering Technology and Business, an education specialist in peer-led team learning, and the Associate Provost. The initial general education reading assessment was conducted in Spring 2012 by the college's Office of Assessment and Institutional Research, which also provided technical support for the program's assessment activities. In Fall 2013, READ participants included six Biology I sections - BIO 1101 (187 students), three Essentials of Marketing sections - MKT 1100 (133 students), and seven Electromechanical Manufacturing Lab sections - EMT 1130 (150 students) READ sections. In spring 2014, there were three BIO 1101 sections (139 students), one MKT 1100 section (34 students), and four EMT 1130 sections (76 students) READ sections. A total of 2 reading faculty members, 13 disciplinary faculty members, and 15 peer leaders participated in the program. Altogether, there were 34 READ sections, and 718 students served by the program during the 2013-2014 academic year. Due to budgetary/staffing limitations, some of the READ sections had no assigned peer leaders.

\section{Faculty Training}

To help launch the program, a literacy specialist trained several content area faculty members in reading strategies in Spring 2013. In Summer 2013 and Spring 2014 additional workshops were offered in which the program principal investigator presented on the program background and instructional approaches to promoting active reading, the faculty liaisons gave discipline specific presentations, and the peer leaders presented on their findings and experiences. In addition, during these workshops, faculty worked in interdisciplinary groups to develop assignments that promote active reading.

\section{Discipline-specific Reading Strategies and Approaches}

In BIO 1101, several modifications were made to the course. First, the syllabus was modified to include the details of the reading assignments. Lecture slides were 
also modified to improve readability and to include details of the reading assignments. Several assignments were developed to ensure that students read the syllabus and to assist with the structure and orientation within the textbook. A detailed reading objective outline was developed for the instructors along with a reading companion for the students. Several assignments were developed to engage students with the reading, some of which were also used as in-class active learning assignments. The assignments were categorized as pre-, during and post-reading assignments (Smyth, 2014). Examples of all these materials are available on the biology Open Lab site (Smyth, 2013).

In EMT 1130, numerous tools and processes were involved in assembling a digital trainer. To help students understand and retain information better, and visualize the steps more clearly, faculty designed feature analysis charts and process maps that were used as pre-lab assignments and assessment tools. These were used repeatedly in varying formats to reinforce learning using the lab manual. Pre-reading assignments were also implemented to relate students' background knowledge to technical information. Other reading and vocabulary activities were assigned to scaffold assignments and enhance students' understanding of technical vocabulary and connect concepts and analyze procedures (But, Kwon, \& Laboy, 2015).

In MKT 1100, marketing faculty chose to develop a series of engaging case studies for students to read and discuss in class. The selected case studies contextualized the concepts students learned in their lectures and textbooks. Lowstakes writing assignments were also designed to help students identify and analyze marketing strategies in the case studies, based on the lectures and textbook knowledge. Group discussions led by peer leaders also facilitated the application of concepts in real life examples. Students were also asked to define key terms to increase their professional vocabularies.

\section{Open Lab}

Open Lab is a web platform at the college previously launched through a Title $\mathrm{V}$ grant where faculty, staff and students can post materials and exchange ideas. The first Open Lab site was constructed for Biology (Smyth, 2013), also the most populated with content. It currently boasts 39 users from the City Tech community. An Open Lab site was also constructed for EMT 1130 (Laboy, 2014). Cengage, and the EMT 1130 manual was self-published by some of the faculty. Responses to questions were on a four-point Likert scale: (1) Poor, (2) Fair, (3) Good, and (4) Excellent.

\section{Results and Discussion}

Over the Fall 2012 to Spring 2014 period, the READ initiative was established at City Tech. The four components of READ were implemented in stages over each semester (Table 1), resulting in a series of faculty development and training workshops, the training of peer leaders and piloting of PLTL reading workshops, several assessments of reading and an Open Lab website for READ to disseminate findings. Faculty were introduced to strategies and approaches to engage students in their reading. Faculty then developed discipline specific assignments and approaches that 
best meet their needs. The activities of READ resulted in faculty and peer leaders trained in reading strategies, the development of discipline specific reading assignments and assessments and the dissemination of our findings both on the web through our Open Lab website and at conferences and meetings. It is notable to mention that the peer leaders also presented on their experiences locally and at national meetings.

The READ initiative had several notable results. Pass rates increased in all three courses in both Fall 2013 and Spring 2014, compared to the non-READ sections in Fall 2011 (baseline data) as is shown in Table 2.

Table 2

Fall 2013 and Spring 2014 READ sections and Fall 2011 (non-READ) Grade/Pass Rate Comparison

\begin{tabular}{|c|c|c|c|c|c|c|c|c|}
\hline $\begin{array}{l}\text { Fall } 2011 \\
\text { Non-READ } \\
\text { Grade } \\
\text { Distribution }\end{array}$ & $\begin{array}{c}\% \\
\text { Pass } \\
\text { C or } \\
\text { Better }\end{array}$ & $\begin{array}{c}\% \\
\text { Pass } \\
\text { D or } \\
\text { Better }\end{array}$ & $\begin{array}{l}\text { Spring } 2014 \\
\text { READ } \\
\text { Grade } \\
\text { Distribution }\end{array}$ & $\begin{array}{c}\% \\
\text { Pass } \\
\text { C or } \\
\text { Better }\end{array}$ & $\begin{array}{c}\% \\
\text { Pass } \\
\text { D or } \\
\text { Better }\end{array}$ & $\begin{array}{c}\text { Fall } 2013 \\
\text { READ } \\
\text { Grade } \\
\text { Distribution }\end{array}$ & $\begin{array}{c}\% \\
\text { Pass } \\
\text { C or } \\
\text { Better }\end{array}$ & $\begin{array}{c}\% \\
\text { Pass } \\
\text { C or } \\
\text { Better }\end{array}$ \\
\hline BIO 1101 & $63.8 \%$ & $76.0 \%$ & $\begin{array}{l}\text { BIO } 1101 \\
\text { (3 sections) }\end{array}$ & $69.8 \%$ & $77.7 \%$ & $\begin{array}{l}\text { BIO } 1101 \\
\text { (6 sections) }\end{array}$ & $64 \%$ & $72 \%$ \\
\hline EMT 1130 & $61.9 \%$ & $65.0 \%$ & $\begin{array}{l}\text { EMT } 1130 \\
\text { (4 sections) }\end{array}$ & $76.3 \%$ & $76.3 \%$ & $\begin{array}{l}\text { EMT } 1130 \\
\text { (7 sections) }\end{array}$ & $78 \%$ & $78 \%$ \\
\hline MKT 1100 & $50.9 \%$ & $56.6 \%$ & $\begin{array}{l}\text { MKT } 1100 \\
\text { (1 section) }\end{array}$ & $61.8 \%$ & $64.7 \%$ & $\begin{array}{l}\text { MKT } 1100 \\
\text { (4 sections) }\end{array}$ & $81 \%$ & $82 \%$ \\
\hline
\end{tabular}

For MKT 1100 the pass rate (A-D) improvement of READ sections compared to Fall 2011 non-READ sections was 25.4\% (Fall 2013) and 8.1\% (Spring 2014); the increase in students who achieved "A-C" was 30.1\% (Fall 2013) and 10.9\% (Spring 2014).

For EMT 1130, the pass rate (A-D) improvement was $24.4 \%$ (Fall 2013) and $11.3 \%$ (Spring 2014); the increase in students who achieved "A-C" was 16.1\% (Fall 2013) and $14.4 \%$ (Spring 2014).

For BIO 1101, there was no increase in the percentage of students who achieved "A-D" and "A-C" or better in Fall 2013; the respective increases in students who achieved "A-D" and "A-C" in Spring 2014 were 1\% and 6\%, respectively. The authors feel that the relatively small increase in pass rate in BIO 1101 could be attributed to the fact that the lab and lecture sections of the course were not linked, and were therefore taught by different instructors. While reading strategies were 
implemented in the lecture, PLTL could not be imbedded into the laboratory course and active reading was not reinforced. The final BIO 1101 grade is $60 \%$ lecture and $40 \%$ lab.

The results of the READ pre- and post-assessments in Fall 2013 for the three courses are shown in Figures 1 to 3.

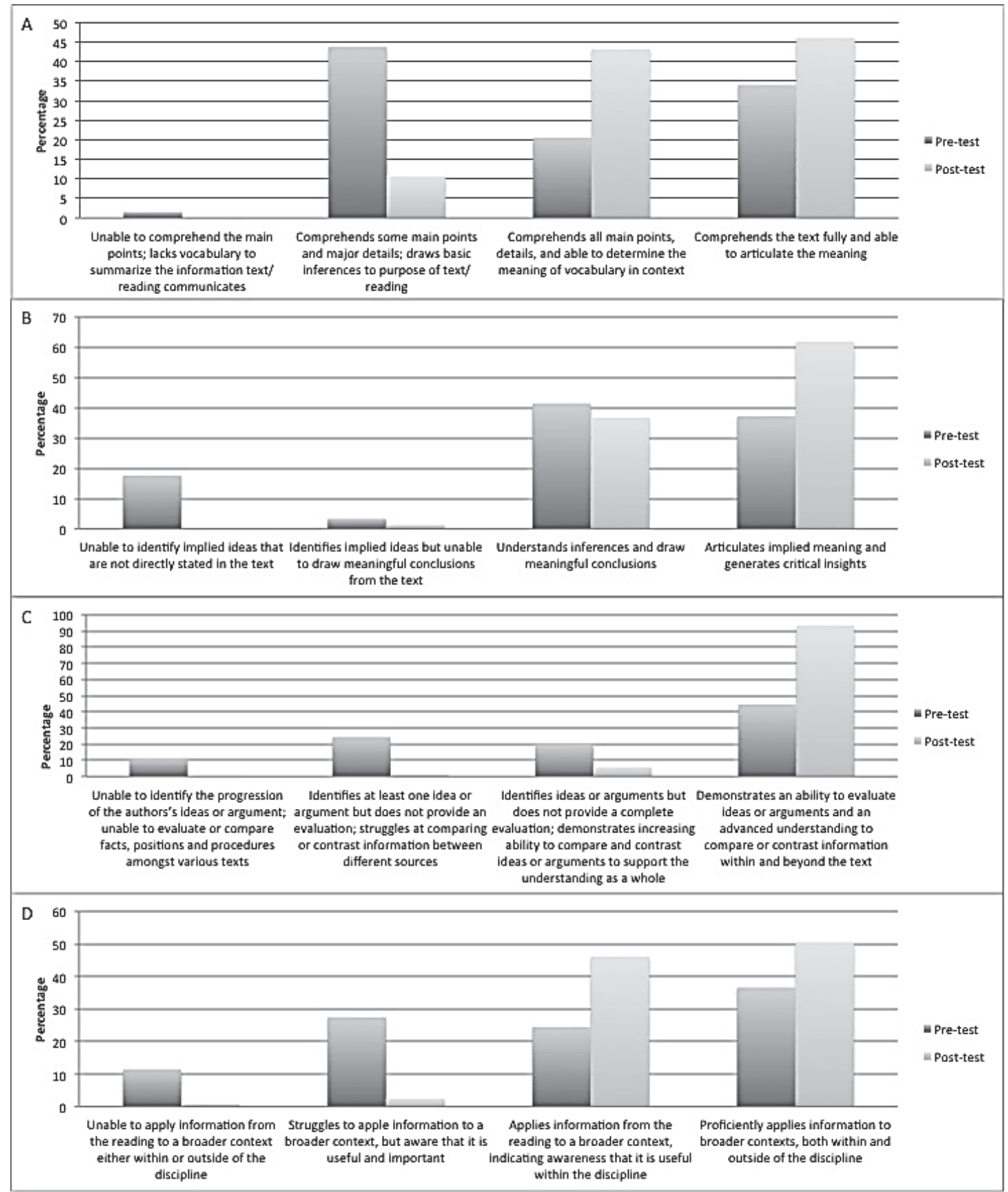

Figure 1a-d. Results of Fall 2013 pre- and post-reading assessment for students in Computer Engineering Technology (CET). 1a. Assessment of comprehension in CET. 1b. Assessment of context in CET. 1c. Assessment of analysis in CET. 1d. Assessment of interpretation in CET. Seven sections of the EMT 1130 course were assessed with 120 students completing the pre-test and 79 completing the post-test. Total enrollment was 150 students. 


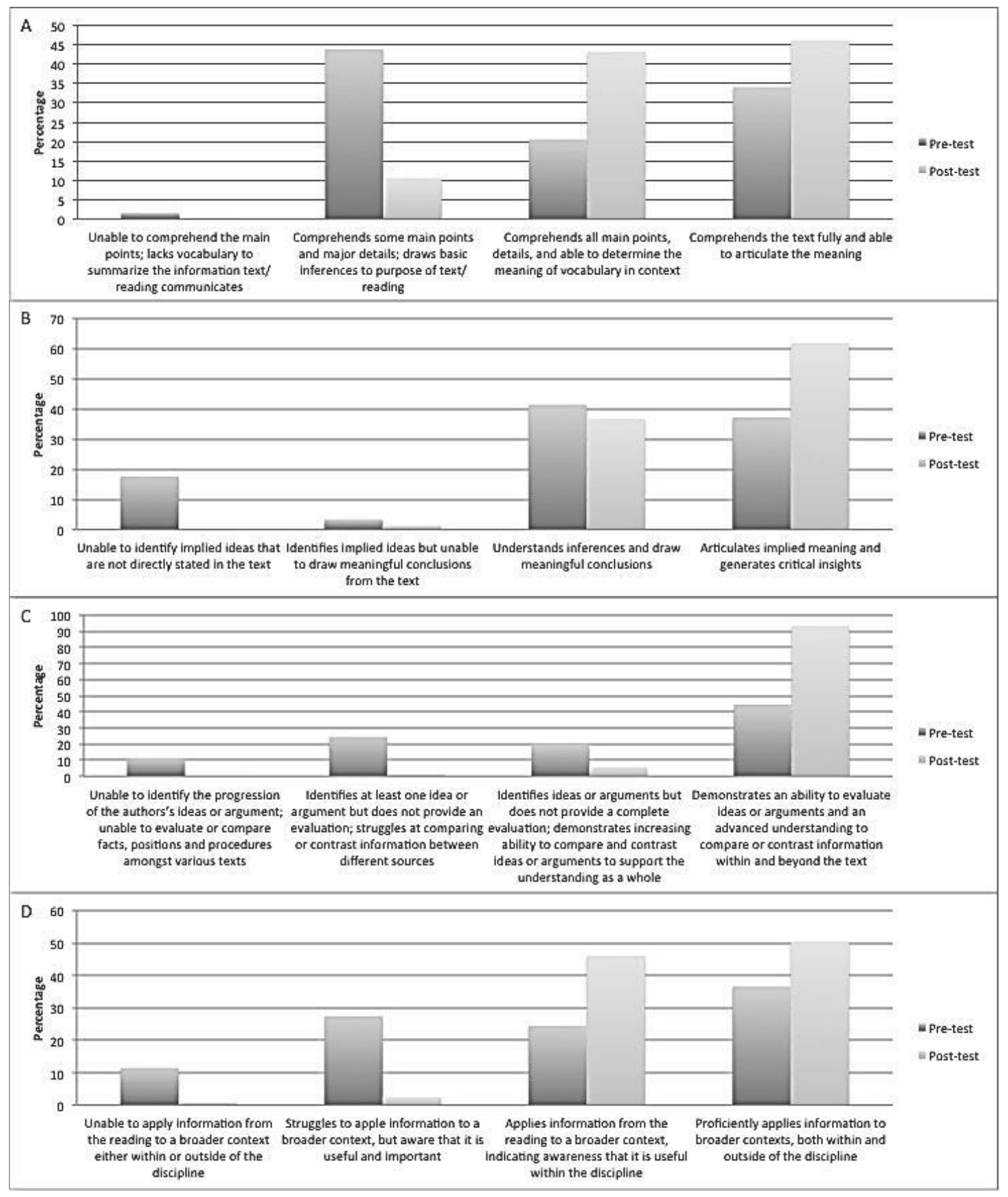

Figure 2a-d. Results of Fall 2013 pre- and post-reading assessment for students in Business (MKT). 2a. Assessment of comprehension in MKT. 2b. Assessment of context in MKT. 2c. Assessment of analysis in MKT. 2d. Assessment of interpretation in MKT. Four sections of the MKT 1100 course were assessed with 66 students completing the pre-test and 65 completing the post-test. Total enrollment was 133 students. 


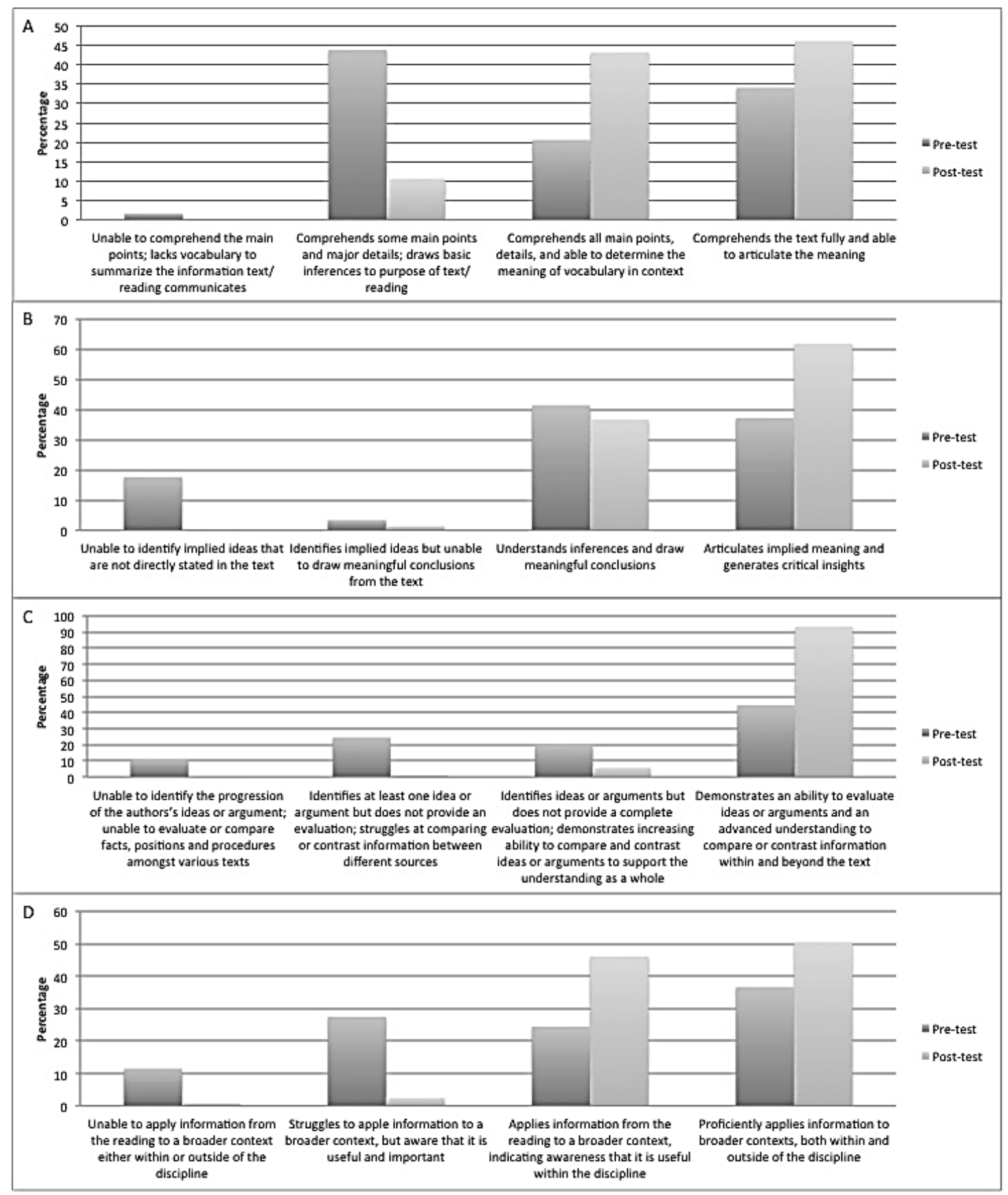

Figure 3a-d. Results of Fall 2013 pre- and post-reading assessment for students in Biological Sciences (BIO). 3a. Assessment of comprehension in BIO. 3b. Assessment of context in BIO. 3c. Assessment of analysis in BIO. 3d. Assessment of interpretation in BIO. Four sections of the BIO 1101 course were assessed with 140 students completing the pre-test and 59 completing the post-test. Total enrollment was 186 students.

Since the scopes and learning goals of the three target courses are different, the student populations also vary. EMT 1130 and MKT 1100 are required courses for Electromechanical Engineering Technology (AAS degree) and Computer Engineering Technology (BTech) and Marketing Management and Sales (AAS degree) and Fashion Marketing (AAS degree) majors, respectively; however, BIO 1101 is a course generally 
taken as either an elective general education course for students of all majors or a required course for bioinformatics and health sciences students.

The content of EMT 1130 is highly specialized and the only text used is the lab manual, which was also used in our pre- and post-assessments. Therefore, there was continuity and consistency between both sets of assessment. The assessment results in Fall 2013 demonstrated significant improvement in student reading. The increase in the percentage of students who met the criteria ( 3 or above) in comprehension, interpretation, analysis, and context ranged from 20 to $30 \%$.

MKT 1100 is a course that requires students to connect content knowledge to real life applications. MKT instructors selected case studies/articles to be used in class from several designated publications, from which we also selected passages for the pre and post-assessments. Even though the articles had different authors, their readability levels were similar and students were somewhat familiar to the structure and language used. The results showed moderate gain in student reading proficiency in the postassessment. The increase in the percentage of students who met the criteria (3 or above) in comprehension, analysis, and interpretation were $6 \%$, $13 \%$, and $10 \%$. There was no marked improvement in context. Compared to EMT 1130 and MKT 1100, the reading requirements of $\mathrm{BIO} 1101$, which consists of

... our faculty team used readings that meaningfully contextualize topics that were covered in class. lecture ( $3 \mathrm{hrs}$ ) and lab (3 hrs), are broader and include diverse topics. The text is also conceptually dense and the chapters are longer when compared to those used in the other two courses. Therefore, students typically depend on lectures rather than reading to learn. For the reading assessments, our faculty team used readings that meaningfully contextualize topics that were covered in class. Newspaper articles with a research focus on biology were used. However, the selected articles varied in levels of complexity and requirements of background knowledge because of the nature of the topics and the manners in which the topics were discussed. While both readings in the pre-and post-assessments were college level, the pre-assessment was a factual report written in direct prose, and the post-assessment passage was based on a research report that consisted of complex ideas and arguments and therefore required more sophisticated cognitive skills and the use of context clues to understand general and technical vocabulary words. The assessment results also reflected that students found the post-assessment more challenging, not so much in understanding details and components in the text, as in making inferences and identifying and summarizing the overall main idea. As a result, the post-assessment showed improvement only in analysis, but not in comprehension, interpretation, and context.

The textbook survey results were also intriguing. We note from data presented in Table 3 that BIO 1101 faculty and students in the READ section with peer leaders rated the textbook (from a commercial publisher) most highly, with the lowest rating by non-READ students. This implied that READ students were able to gain more value from the text and thus better appreciated it. The reverse trend is seen in EMT 1130 with EMT faculty and students in the READ section with peer leaders giving the self-published, non-peer reviewed manual the lowest rating. A quick review of the EMT manual revealed typos, misaligned drawings, inaccurate instructions, etc. 
Faculty and READ students with peer leaders may have been most attuned to the manual's shortcomings. These errors in the manual have been addressed.

Table 3

Average Textbook Evaluation Survey Results

\begin{tabular}{|c|c|c|c|c|c|c|c|c|c|}
\hline & $\begin{array}{c}\text { BIO } 1101 \\
\text { Faculty }\end{array}$ & $\begin{array}{c}\text { BIO } \\
1101 \\
\text { students } \\
\text { READ } \\
\text { with } \\
\text { peer } \\
\text { leaders }\end{array}$ & $\begin{array}{c}\text { BIO } \\
1101 \\
\text { students } \\
\text { READ } \\
\text { no peer } \\
\text { leaders }\end{array}$ & $\begin{array}{c}\text { BIO } \\
1101 \\
\text { students } \\
\text { non- } \\
\text { READ }\end{array}$ & $\begin{array}{c}\text { EMT } \\
1130 \\
\text { Faculty }\end{array}$ & $\begin{array}{c}\text { EMT } \\
1130 \\
\text { students } \\
\text { READ } \\
\text { with } \\
\text { peer } \\
\text { leaders }\end{array}$ & $\begin{array}{c}\text { EMT } \\
1130 \\
\text { students } \\
\text { READ } \\
\text { no peer } \\
\text { leaders }\end{array}$ & $\begin{array}{c}\text { EMT } \\
1130 \\
\text { students } \\
\text { non- } \\
\text { READ }\end{array}$ & $\begin{array}{c}\text { MKT } \\
1100 \\
\text { Faculty }\end{array}$ \\
\hline $\begin{array}{l}M d n \\
\text { Resp. }\end{array}$ & 3.19 & 3.24 & 2.9 & 2.57 & 2.89 & 2.94 & 2.99 & 3.12 & 2.7 \\
\hline $\begin{array}{l}N \text { of } \\
\text { Resp. }\end{array}$ & 5 & 30 & 27 & 13 & 5 & 15 & 21 & 10 & 1 \\
\hline
\end{tabular}

Note. Evaluation rating scale: (1) Poor, (2) Fair, (3) Good, (4) Excellent

As reflected in the faculty workshop feedback survey (see Appendix B), both full-time and part-time faculty participants found our workshop effective and were eager to apply the techniques they learned. From our observation, most of the participants were exposed to active reading strategies for the first time. Some of them also expressed interest in more in-depth discussion specific to their disciplines. This was done in subsequent meetings and collaborative activities throughout the semester.

\section{Limitations of the Study}

Improvements in grade distribution pre-READ (Fall 2011) to post-READ (Fall 2013 and Spring 2014) were significant evidence of the success of this program. However, a detailed analysis of student characteristics was not made to confirm that these were appropriate comparison groups. It was just assumed that since the institution had not changed markedly, neither had the students.

In order to assess students' reading proficiency in the target courses, the assessment tools used were not general and standardized, but discipline-specific. This presented a challenge to the faculty team who designed the assessment tools to ensure consistency between text complexities of the passages used and test items in the sets of pre- and post-assessments, although the same rubric was used in the process. While the same instructor rated the pre- and post-

...most of the participants were exposed to active reading strategies for the first time. reading assessment results, another limitation of this study is that the resources to verify the reliability of the pre- and post-reading assessment tests were not available.

Our initial plan was to embed peer-led team learning in class sessions. However, because of scheduling of CUNY first, the university's platform for course 
scheduling and registration, BIO 1101 lecture and lab sections could not be linked as planned. As a result, different instructors taught lecture and lab sections. This caused difficulties in the implementation of PLTL workshops and grade analysis of the course. We observed that student attendance was not as satisfactory outside the scheduled class time as in embedded PLTL workshops. The lack of a uniform BIO 1101 final exam was another problem we faced in student assessment.

Lastly, another limitation was sampling. There was a relatively low response rate on the textbook survey.

\section{Conclusions}

The multimodal design of READ provides an interactive teaching and learning environment. Instructors are equipped with active reading strategies and are able to design discipline-specific assignments that make reading necessary and relevant. Students are engaged in active reading in both individual and group settings. Peer led team-reading workshops facilitated by student peer leaders additionally supported students.

The READ Open Lab site has been a useful resource for READ instructors. Populated with reading strategies, sample assignments and activities, the site also serves as a platform for exploring and sharing questions, feedback, and best practices.

Even though reading is an essential part of learning in all disciplines, content area literacy has not been addressed in most content area classrooms. Given that faculty members in the disciplines are generally unfamiliar with the "reading to learn" approach, it took significant effort to recruit faculty participants. The reading faculty team conducted several college-wide workshops to share the importance of content area literacy instruction. Since most of the participating instructors were adjunct faculty, their levels of commitment tended to vary, mainly due to time constraints. The program's success relied on not only sound reading strategies and teaching approaches, but also faculty involvement and team communication in the implementation process.

Presently, we continue our efforts to enhance our students' skills in "reading to learn" across the disciplines. We have expanded our focus on improving student reading to include additional disciplines including Architectural Technology, Dental Hygiene, Accounting, and Mathematics Education in 2015-2016.

\section{Acknowledgments}

The pilot of this initiative was funded by a City University of New York Office of Academic Affairs (CUNY OAA) grant. We are grateful to our colleagues Henry Laboy, Cindy Rodrigo, James Leung, Paul Salisbury and AE Dreyfuss for their participation and contributions to the initiative. We would also like to thank Tammie Cumming and her staff in the Office of Assessment and Institutional Research, Nina Bannett, Sunghoon Jang, Laina Karthikeyan, and Anne Zissu for their support as department chairs, Julia Jordan and her staff in the Faculty Commons, and Katherine Figueroa (Borough of Manhattan Community College) for generously sharing her wisdom and expertise. Finally, we would like to express our appreciation to Provost Bonne August for her continuous support. We would like to acknowledge our peer 
leaders: Shannon Massry, George Cobos, Ayesha Rasool, Loudjina Pierre, Yanna Chen, Hikma Abdulghani, Monika Ciereszko, Andris Pinkhasik, and Adedamola Shomoye.

\section{References}

ACT. (2012, August 8). The condition of college and career readiness 2012. http://www.act.org/research/policymaker s/cccr12/readiness1.html Retrieved from http://www.act.org/content/dam/act/uns ecured/documents/CCCR12-

NationalReadinessRpt.pdf

Alexander, P. A., Schallert, D. L., \& Hare, V. C. (1991). Coming to terms: How researchers in learning and literacy talk about knowledge. Review of Educational Research, 61, 315-343. Retrieved from http://www.jstor.org/stable/1170635

Alexander, P. A., \& Jetton, T. L. (2000). Learning from text: A multidimensional and developmental perspective. In M. L. Kamil, P. B. Mosenthal, P. D. Pearson, \& R. Barr (Eds.), Handbook of reading research (Vol. 3, pp. 285-310). Mahwah, NJ: Erlbaum.

Alvermann, D. E., \& Moore, D. W. (1991). Secondary school reading. In R. Barr, M. L. Kamil, P. B. Mosenthal, \& P. D. Pearson (Eds.), Handbook of reading research (Vol. 2, pp. 951-983). New

York, NY: Longman.

But, J. C., Kwon, O., \& Laboy, H. (2015). Reading effectively in first year electromechanical

courses. Proceedings of the $7^{\text {th }}$ (FYEE) First Year Engineering Experience Conference, T3D, 5070. Retrieved from http://fyee.asee.org/FYEE2015/index.htm

Chambliss, M. J. (1995). Text cues and strategies successful readers use to construct the gist of lengthy written arguments. Reading Research Quarterly, 30, 778-807. doi: 10.2307/748198
Chapman, J. (1983). Reading development and cohesion. London, England: Henemann Educational Books.

Conley, D. T., Aspengren, K., Stout, O., \& Veach, D. (2006). College board advanced placement best practices course study report. Retrieved from http://www.epiconline.org/college-boardadvanced-placement-best-practices-coursestudy/

Conley, D. T. (2007). Redefining college readiness. Eugene, OR: Educational Policy Improvement Center. Retrieved from http://www.epiconline.org/collegeboard-advanced-placement-bestpractices-course-study/

Conley, D. T. (2008). Rethinking College Readiness. New England Journal of Higher Education, 22(5), 24-26. Retrieved from http://www.csub.edu/eapriap/day1/Rethinking\%20College\%20Rea diness.pdf

Crystal Springs Books. (2012). Staff development for educators/textbook evaluation form. Retrieved from Staff Development for Educators website: http://www.sde.com/Downloads/Teacher Resources/ di_text/textbook_evaluation.pdf

Fang, Z., \& Schleppegrell, M. J. (2010). Disciplinary literacies across content areas: Supporting secondary reading through functional language analysis. Journal of Adolescent $\mathcal{E}$ Adult Literacy, 53, 587-597. doi: 10.1598/JAAL.53.7.6 
Graesser, A. C., Milis, K. K., \& Zwann, R. A. (1997). Discourse comprehension. Annual Review of Psychology, 48, 163-189. doi: 10.1146/annurev.psych.48.1.163

Hall, L. A. (2005). Teachers and content area reading: Attitude, beliefs, and changes. Teaching and Teacher Education, 21, 403-414.

doi:10.106.1016/j.tate.2005.01.009

Kintsch, W., \& Rawson, K. A. (2005). Comprehension. In M. J. Snowling \& C. Hulme (Eds.), The science of reading: $A$ handbook (pp. 209-226). Oxford, England: Blackwell Publishing.

Kletzien, S. B. (1992). Proficient and less proficient comprehenders' strategy use for different top-level structures. Journal of Literacy Research, 24(2), 191-215.

Laboy, H. (2014). Retrieved from City Tech OpenLab website:

https://openlab.citytech.cuny.edu/emt113 $0 /$

Mader, S. S. (1998). Biology. International edition. McGraw Hill.

Meltzer, J. (2002). Adolescent literacy resources: Linking research and practice. Providence, RI: Brown University.

Moje, E. B. (2008). Foregrounding the disciplines in secondary literacy teaching and learning: A call for change. Journal of Adolescent \& Adult Literacy, 52(2), 96-107. doi: 10.1598/ JAAL.52.2.1

Moore, P. J., \& Sceval, J. J. (1997). Learning from texts and visual aids: A developmental perspective. Journal of Research in Reading, 20, 205-223. doi: 10.1111/1467-9817.00033
Nippold, M. A., \& Martin, S. T. (1989). Idiom interpretation in isolation versus context: A developmental study with adolescents. Journal of Speech and Hearing Research, 35, 108-118. doi: 10.1044/jshr.3201.59

Pressley, M., \& Afflerbach, P. (1995). Verbal protocols of reading: The nature of constructively responsive reading. Hillsdale, NJ: Erlbaum.

Pride, W. M., Ferrell, O. C., Lukas, B. A., Schembri, S., \& Niininen, O. (2012). Marketing principles. Cengage Learning.

Richardson, J. S., Morgan, R. F., \& Fleener, C. (2012). Reading to learn in the content areas. Cengage Learning.

Schemo, D. J. (2006, September 2). At 2year colleges, students eager but unprepared. Retrieved from New York Times website: http://www.nytimes.com/2006/09/02/edu cation/02college.html

Shanahan, T., \& Shanahan, C. (2008). Teaching disciplinary literacy to adolescents: Rethinking content-area literacy. Harvard Educational Review, 78(1), 40-59. doi: 10.17763/ haer.78.1.v62444321p602101

Smyth, D. (2013). Retrieved from OPENLAB at City Tech website: https://openlab.citytech.cuny.edu/readin geffectivelyacrossthediscilpines/

Smyth, D. S. (2014, May). Reading effectively across the disciplines: Focus on biology. Poster session presented at the Teaching Professor Conference. Boston, MA. 
Snyder, J. J., Sloane, J. D., Dunk, R. D. P., \& Wiles, J. R. (2016) Peer-led team learning helps minority students succeed. PLoS Biol, 14(3): e1002398. doi: 10.1371/journal.pbio.1002398

Stewart, R. A., \& O'Brien, D. G. (1989). Resistance to content area reading: A focus on preservice teachers. Journal of Reading, 32(5), 396-401.
Zygouris-Coe, V. (2012, July 24). Eyes on disciplinary literacy. International Literacy Association: Literacy Daily Blog. Retrieved from http://literacyworldwide.org/blog/ literacy-daily/2012/07/24/eyes-ondisciplinary-literacy

\section{Appendix A}

Reading Assessment Rubric

\begin{tabular}{|c|l|l|l|l|}
\hline $\begin{array}{c}\text { Performance } \\
\text { Criteria }\end{array}$ & $\begin{array}{c}\text { Does Not } \\
\text { Meet } \\
\text { Criterion }\end{array}$ & $\begin{array}{l}\text { Approaching } \\
\text { Criterion }\end{array}$ & \multicolumn{1}{|c|}{$\begin{array}{c}\text { Meets } \\
\text { Criterion }\end{array}$} & \multicolumn{1}{c|}{$\begin{array}{c}\text { Surpasses } \\
\text { Criterion }\end{array}$} \\
\hline Comprehension & $\begin{array}{l}\text { Unable to } \\
\text { comprehend } \\
\text { the main } \\
\text { points; lacks } \\
\text { vocabulary to } \\
\text { summarize the } \\
\text { information } \\
\text { text/reading } \\
\text { communicates }\end{array}$ & $\begin{array}{l}\text { Comprehends } \\
\text { some main } \\
\text { points and } \\
\text { major details; } \\
\text { draws basic } \\
\text { inferences to } \\
\text { purpose of } \\
\text { text/reading }\end{array}$ & $\begin{array}{l}\text { Comprehends } \\
\text { all main } \\
\text { points, details, } \\
\text { and able to } \\
\text { determine the } \\
\text { meaning of } \\
\text { vocabulary in } \\
\text { context }\end{array}$ & $\begin{array}{l}\text { Comprehends } \\
\text { the text fully } \\
\text { and able to } \\
\text { articulate the } \\
\text { meaning }\end{array}$ \\
\hline Context & $\begin{array}{l}\text { Unable to } \\
\text { apply } \\
\text { information } \\
\text { from the } \\
\text { reading to a } \\
\text { broader } \\
\text { context either } \\
\text { within or } \\
\text { outside of the } \\
\text { discipline }\end{array}$ & $\begin{array}{l}\text { Struggles to } \\
\text { apple } \\
\text { information to } \\
\text { a broader } \\
\text { context, but } \\
\text { aware that it } \\
\text { is useful and } \\
\text { important }\end{array}$ & $\begin{array}{l}\text { Applies } \\
\text { information } \\
\text { from the } \\
\text { reading to a } \\
\text { broader } \\
\text { context, } \\
\text { indicating } \\
\text { awareness that } \\
\text { it is useful } \\
\text { within the } \\
\text { discipline }\end{array}$ & $\begin{array}{l}\text { Proficiently } \\
\text { applies } \\
\text { information to } \\
\text { broader } \\
\text { contexts, both } \\
\text { within and } \\
\text { outside of the } \\
\text { discipline }\end{array}$ \\
\hline
\end{tabular}




\begin{tabular}{|c|c|c|c|c|}
\hline Analysis & $\begin{array}{l}\text { Unable to } \\
\text { identify the } \\
\text { progression of } \\
\text { the author's } \\
\text { ideas or } \\
\text { argument; } \\
\text { unable to } \\
\text { evaluate or } \\
\text { compare facts, } \\
\text { positions and } \\
\text { procedures } \\
\text { amongst } \\
\text { various texts }\end{array}$ & $\begin{array}{l}\text { Identifies at } \\
\text { least one idea } \\
\text { or argument } \\
\text { but does not } \\
\text { provide an } \\
\text { evaluation; } \\
\text { struggles at } \\
\text { comparing or } \\
\text { contrast } \\
\text { information } \\
\text { between } \\
\text { different } \\
\text { sources }\end{array}$ & $\begin{array}{l}\text { Identifies ideas } \\
\text { or arguments } \\
\text { but does not } \\
\text { provide a } \\
\text { complete } \\
\text { evaluation; } \\
\text { demonstrates } \\
\text { increasing } \\
\text { ability to } \\
\text { compare and } \\
\text { contrast ideas } \\
\text { or arguments } \\
\text { to support the } \\
\text { understanding } \\
\text { as a whole }\end{array}$ & $\begin{array}{l}\text { Demonstrates } \\
\text { an ability to } \\
\text { evaluate ideas } \\
\text { or arguments } \\
\text { and an } \\
\text { advanced } \\
\text { understanding } \\
\text { to compare or } \\
\text { contrast } \\
\text { information } \\
\text { within and } \\
\text { beyond the } \\
\text { text }\end{array}$ \\
\hline Interpretation & $\begin{array}{l}\text { Unable to } \\
\text { identify } \\
\text { implied ideas } \\
\text { that are not } \\
\text { directly stated } \\
\text { in the text }\end{array}$ & $\begin{array}{l}\text { Identifies } \\
\text { implied ideas } \\
\text { but unable to } \\
\text { draw } \\
\text { meaningful } \\
\text { conclusions } \\
\text { from the text }\end{array}$ & $\begin{array}{l}\text { Understands } \\
\text { inferences and } \\
\text { draw } \\
\text { meaningful } \\
\text { conclusions }\end{array}$ & $\begin{array}{l}\text { Articulates } \\
\text { implied } \\
\text { meaning and } \\
\text { generates } \\
\text { critical insights }\end{array}$ \\
\hline
\end{tabular}

\section{Appendix B}

READ Faculty Workshop Feedback Survey (August 2013)

1. Which of the following best describes your position at City Tech?

Number of Responses: 15

\begin{tabular}{|c|c|c|}
\hline Full-time faculty & Part-time faculty & Administrator/Staff \\
\hline 3 & 11 & 1 \\
\hline $20.00 \%$ & $73.30 \%$ & $6.70 \%$ \\
\hline
\end{tabular}

2. Please indicate your department/program/area affiliation:

Number of Responses: 13

\begin{tabular}{|l|l|}
\hline Biology & 6 \\
\hline Business/Marketing & 3 \\
\hline Computer Engineering Technology & 4 \\
\hline
\end{tabular}

3. For the following statements, please indicate your level of agreement:

Number of Responses: 15 


\begin{tabular}{|l|l|l|l|l|l|l|}
\hline & Strongly & $\begin{array}{l}\text { Moderately } \\
\text { Agree }\end{array}$ & Neutral & $\begin{array}{l}\text { Moderately } \\
\text { Disagree }\end{array}$ & $\begin{array}{l}\text { Strongly } \\
\text { Disagree }\end{array}$ & Mean \\
\hline Overall Average & $94.1 \%$ & $5.9 \%$ & & & & 4.94 \\
\hline $\begin{array}{l}\text { The } \\
\text { program/workshop } \\
\text { was well organized. }\end{array}$ & 15 & $100 \%$ & & & & \\
\hline $\begin{array}{l}\text { The presenter's } \\
\text { knowledge of the } \\
\text { content contributed } \\
\text { to my } \\
\text { understanding of } \\
\text { the material. }\end{array}$ & 15 & $100.00 \%$ & & & & 5.00 \\
\hline
\end{tabular}




\begin{tabular}{|c|c|c|c|}
\hline \multirow{2}{*}{$\begin{array}{l}\text { The } \\
\text { program/workshop } \\
\text { met or exceeded my } \\
\text { expectations. }\end{array}$} & 12 & 3 & 4.80 \\
\hline & $80.00 \%$ & $20.00 \%$ & \\
\hline \multirow{2}{*}{$\begin{array}{l}\text { I would } \\
\text { recommend this or } \\
\text { other similar } \\
\text { programs to my } \\
\text { colleagues. }\end{array}$} & 14 & 1 & 4.98 \\
\hline & $93.30 \%$ & $6.7 \%$ & \\
\hline
\end{tabular}


Juanita C. But is Associate Professor of English and Reading Coordinator at New York City College of Technology/City University of New York, where she teaches literature, writing, and developmental reading. She has been the principal investigator of Reading Effectively Across the Disciplines (READ). since the program's inception in 2013. She also served in the Research and Assessment Committee of the CUNY Reading Discipline Council and the CUNY Reading Assessment Panel. She received her PhD in Comparative Literature from the State University of New York at Buffalo. In addition to reading and disciplinary literacy, her research interests and publications focus on New York City and diasporic literature. She has been a volunteer leader and coordinator in a literacy program in Manhattan for over ten years.

Pamela Brown is Associate Provost at New York City College of Technology/City University of New York, where she previously served six years as the Dean of the School of Arts E Sciences. She is a faculty member in the Chemistry Department. The Emerging Scholars Program, an undergraduate research program founded under her leadership. She recently served on the National Research Council of the National Academy of Sciences Committee. She also served as a Program Director in the Division of Undergraduate Education at the National Science Foundation. Her work has focused on creating initiatives to improve the retention and recruitment of students interested in careers in STEM fields. She was the principal investigator of an NSF grant, "Metropolitan Mentors: (MMNet): Growing an Urban STEM Talent Pool across New York City," She has a PhD in chemical engineering from Polytechnic University (now NYU Tandon School of Engineering) and an SM in Chemical Engineering Practice from the Massachusetts Institute of Technology (MIT).

Davida S. Smyth is an Associate Professor of Natural Sciences at Mercy College, Dobbs Ferry, where she teaches Environmental Science, Microbiology, Genetics and Introductory Biology. She has been the program coordinator for the Biomedical Informatics Program at New York City College of Technology and is currently an instructor of Bioinformatics at NYU Tandon School of Engineering. She did her Bachelors and PhD, both in Microbiology at the University of Dublin, Trinity College in Ireland and her postdoctoral training at New York Medical College, the University of Mississippi Medical Centre and New York University, where she maintains assistant research scientist status in the Skirball Institute of NYU Langone Medical Center. Her research focuses on the role of mobile DNA, biofilm production and antibiotic resistance in clinical and environmental strains of Staphylococci. In Spring 2016, she was elected a SENCER Leadership Fellow for her work to improve the biology undergraduate curriculum especially in the area of student reading skills in STEM disciplines, peer led team learning in Biology and incorporating undergraduate research experiences. 